oped economic and administrative life of the regions through which they pass. Here once again Mr. Margary has shown the way with his Wealden studies; but the process requires extension to the whole country. Locally the details of suburban roads and bypasses in relation to towns also need more intensive study whore conditions still permit this.

Therefore, while we welcome the completion of Mr. Margary's great task and applaud the skill which he has shown in handling and presenting a great body of material in convenient form, it must be made plain that this is not the ond. These two volumes come at a time of growing public interest in archæology. They are passing into the hands of $a$ wider public than was the case of archrological books even twenty years ago, and they will certainly play a great part in promoting this long-established line of study. They are at once a landmark and a point of departure.

C. W. Phrllites

\section{THE ESSAYIST OF THE BRITISH COUNTRYSIDE}

\section{Field and Farm}

Essays now First Collected, with some from MSS. By Richard Jefferies. Edited with an Introduction and Notes by Samuel J. Looker. Pp. 191. (London : Phoenix House, Ltd., 1957.) 15s. not.

$\mathrm{R}$ ICHARD JEFFERIES was one of the most highly gifted writers about the English countryside in the whole of our history. He was born in 1848 at the little village of Coate near Swindon; his father was a small farmer, unpractical but a keen observer of Nature and natural phenomena, and also a great reader with a considerable library of the best authors. He introduced Richard to Homer, interested him in the neighbouring Roman encampments, and trained him in the habits of the naturalists. Richard did not, however, follow his father on the farm, but at the age of seventeen became reporter for a local paper and afterwards joined the staff of the Wiltshire and Gloucestershire Standard. Some twelve years later he moved to Surbiton and became a free-lance journalist, writing articles on the countryside for The Times, the Pall Mall Gazette, and some of the agricultural journals, especially the Live Stock Journal. He also wrote three indifferent novels and other books which were not all appreciated. Two, issued by Longmans, "The Story of my Heart" (1883) and "Red Deer" (1884), had been failures; Longmans consequently refused "The Life of the Fields", which, however, was later published. "Amaryllis at the Fair" was rejected by Bentley but afterwards accepted by Sampson Low (1887). His clientele was highly esoteric.

Jofferies started collecting his scattered writings into volumes but died before the task was completed. Many would have been lost; they were mostly unsigned or were under a variety of pseudonyms, and no complete list could be found. By prodigious efforts, for which all admirers of Jefferies must be profoundly grateful, Mr. S. J. Looker has unearthed a number of them. He issued some in 1948 under the title "Chronicles of the Hedges" and now a further group in this volume, "Field and Farm".

The essays are short, compact, full of close observa. tion and very attractively written. They cover one of the most interesting periods in the history of the British countryside, the 1870's and 1880's, when the brilliantly successful golden age of British farming was giving place to the terrible depression that lasted until about 1900, and his vividly recorded reminiscences of older people take the story back into the period when farms and villages were largely self-contained and had little personal contact with the outside world. It was the milk traffic with London that first brought news-sheets-weeklies, not yet dailies-into his country : the most popular items were local squabbles, slashing attacks on established institutions, murders and other crimes spicily related. He tells of other new troubles: of town trespassers breaking farm fences, trampling down crops, and allowing their dogs to chase sheep; except that there is no mention of litter, all this might have been written to-day. $\mathrm{He}_{\theta}$ is heavily down on some of the newfangled innovations : the newly introduced lunch which broke up his day and spoiled his dinner, the "heathenish Tories" with their Primrose League seducing the villagors, the parson that refused burial to a Noneonformist baby, and the growing power of money.

Most of his writing, however, is about the common things of the countryside : the birds, the flowers, the trees and the fields. His descriptions are not simply accurate-for he was a sound observer-thoy are expressed in delicately appropriate language convey. ing something of the elusive beauty of the things $h \theta$ saw. He was essentially a solitary figure, spending his years, especially the later ones, not in the quest for personal advancement but in communing with Nature, trying to see beyond the mystery of which he was conscious and yet could never penetrate; it is this that gives the special quality to his writings.

His last five years were darkened by illness : ho died in 1887 at the age of thirty-nine. Ho lies buried at Broadwater, Worthing, near W. H. Hudson, the one who comes nearest to him in quality though writing a little later in time. Mr. Looker is to be congratulated on his discovery of these essays, and the Phoenix Press on presenting them so well.

\section{E. John Russell}

\section{INSTINCT IN MAN}

\section{Instinct in Man in the Light of Recent Work in Comparative Psychology}

By Dr. Ronald Fletcher. Pp. 248. (London : George Allen and Unwin, Ltd., 1957.) 40s. net.

7 The HERE seoms to be a pendulum-swing in our thinking about some of the more general aspects of human behaviour. At one time they are regarded as a product of biological forces inherited by overy momber of the spocies; at another, the environment is held to be all-powerful.

During the past thirty years or so we have moved out to the environmental extreme. Even in the clinical field, where the biologically orionted theorios of Freud have gained wide acceptiance, the part of psychoanalysis that has been most influential relates to the effects of the early environment. The pendulum is now beginning to swing back.

Recently the ethologists, Lorenz, 'Tinbergen, Thorpe and others, basing their studies mainly on animal behaviour, have shown that instinct is not 